\title{
Selection of Nutrient Used in Biogenic Healing Agent for Cementitious Materials
}

\author{
Eirini Tziviloglou*, Virginie Wiktor, Henk M. Jonkers and Erik Schlangen \\ Microlab, Department of Materials and Environment, Delft University of Technology, Delft, Netherlands
}

Biogenic self-healing cementitious materials target on the closure of micro-cracks with precipitated inorganic minerals originating from bacterial metabolic activity. Dormant bacterial spores and organic mineral compounds often constitute a biogenic healing agent. The current paper focuses on the investigation of the most appropriate organic carbon source to be used as component of a biogenic healing agent. It is of great importance to use an appropriate organic source, since it will first ensure an optimal bacterial performance in terms of metabolic activity, while it should, second, affect the least the properties of the cementitious matrix. The selection is made among three different organic compounds, namely calcium lactate (CaL), calcium acetate (CaA), and sodium gluconate $(\mathrm{NaG})$. The methodology that was used for the research was based

OPEN ACCESS

Edited by:

Francesco Baino,

Politecnico di Torino, Italy

Reviewed by:

Ali Keyvanfar,

Universiti Teknologi Malaysia,

Malaysia

Andrew C. Heath,

University of Bath,

United Kingdom

*Correspondence:

Eirini Tziviloglou

e.tziviloglou@tudelft.nl

Specialty section:

This article was submitted to Biomaterials,

a section of the journal

Frontiers in Materials

Received: 28 March 2017

Accepted: 30 May 2017

Published: 19 June 2017

Citation:

Tziviloglou E, Wiktor V, Jonkers HM and Schlangen E (2017) Selection of

Nutrient Used in Biogenic Healing

Agent for Cementitious Materials.

Front. Mater. 4:15.

doi: 10.3389/fmats.2017.00015 on continuous and non-continuous oxygen consumption measurements of washed bacterial cultures and on compressive strength tests on mortar cubes. The oxygen consumption investigation revealed a preference for $\mathrm{CaL}$ and $\mathrm{CaA}$, but an indifferent behavior for $\mathrm{NaG}$. The compressive strength on mortar cubes with different amounts of either CaL or CaA (up to $2.24 \%$ per cement weight) was not or it was positively affected when the compounds were dissolved in the mixing water. In fact, for CaL, the increase in compressive strength reached $8 \%$, while for CaA, the maximum strength increase was $13.4 \%$.

Keywords: biogenic healing agent, oxygen consumption, oxidation of organic carbon, compressive strength, calcium lactate, calcium acetate, sodium gluconate

\section{INTRODUCTION}

Cracking is an unavoidable characteristic of concrete that originates from its brittle nature, and it is a sign that the tensile strength has been locally exceeded. Micro-cracks do not necessarily put in danger the integrity of the structure, yet, they can impair its durability (Weiss, 1999; Schlangen and Joseph, 2009). The concrete that is able to repair itself; i.e., self-healing concrete, is an approach that has been adapted the last two decades in order to address this problem (de Rooij et al., 2013). The technology targets on the closure of micro-cracks by the release of the healing agent that pre-exists in the bulk concrete. Among various healing agent types, a relatively novel approach is the biogenic healing agent, which usually contains dormant bacterial spores and organic mineral compounds acting as bacterial nutrient. Active bacteria can deposit calcium carbonate $\left(\mathrm{CaCO}_{3}\right)$ and other inorganic minerals, seal the open cracks and, therefore, sustain the integrity of the structure by closing the road to harmful substances.

During microbially induced calcium carbonate precipitation, organisms are able to secrete one or more metabolic products $\left(\mathrm{CO}_{3}^{2-}\right)$ that react with ions $\left(\mathrm{Ca}^{2+}\right)$ in the environment resulting in the 
subsequent precipitation of minerals (Anbu et al., 2016). Although there are several bacterial species that are known to produce $\mathrm{CaCO}_{3}$, not all of them can be functional in the high alkaline concrete environment. In addition, different metabolic pathways are employed by the bacteria for the precipitation of $\mathrm{CaCO}_{3}$ depending on the species and the environmental conditions (Jonkers et al., 2015). The biogenic self-healing agents, which are frequently encountered in the literature, follow three different metabolic routes; i.e., the enzymatic hydrolysis of urea (Ramachandran et al., 2001; De Muynck et al., 2008; Wang et al., 2014), the oxidation of organic carbon (Jonkers et al., 2010; Wiktor and Jonkers, 2011; Jonkers and Mors, 2012; Stuckrath et al., 2014; Xu and Yao, 2014; Sierra Beltran et al., 2015; Paine et al., 2016; Tziviloglou et al., 2016), and the anoxic oxidation of organic carbon (Ersan, 2016).

This paper discusses the oxidation of organic carbon system. In this study, bacterial spores obtained from three different isolates from the genus Bacillus are packed in concrete together with yeast extract (YE) and a calcium-based organic carbon source, all embedded in lightweight aggregates (LWA). The YE helps the spores to germinate and grow, while the organic carbon source acts as nutrient that the active cells can decompose and produce carbon dioxide $\left(\mathrm{CO}_{2}\right)$ and $\mathrm{CaCO}_{3}$ as presented in Eqs 1-3 for the case of calcium lactate $(\mathrm{CaL})\left(\mathrm{CaC}_{6} \mathrm{H}_{10} \mathrm{O}_{6}\right)$ (Wiktor and Jonkers, 2011), calcium acetate $(\mathrm{CaA})\left(\mathrm{CaC}_{4} \mathrm{H}_{6} \mathrm{O}_{4}\right)$, and sodum gluconate $(\mathrm{NaG})\left(\mathrm{NaC}_{6} \mathrm{H}_{11} \mathrm{O}_{7}\right)$, respectively.

$$
\begin{gathered}
\mathrm{CaC}_{6} \mathrm{H}_{10} \mathrm{O}_{6}+6 \mathrm{O}_{2} \rightarrow \mathrm{CaCO}_{3}+5 \mathrm{CO}_{2}+5 \mathrm{H}_{2} \mathrm{O} \\
\mathrm{CaC}_{4} \mathrm{H}_{6} \mathrm{O}_{4}+4 \mathrm{O}_{2} \rightarrow \mathrm{CaCO}_{3}+3 \mathrm{CO}_{2}+3 \mathrm{H}_{2} \mathrm{O} \\
\mathrm{NaC}_{6} \mathrm{H}_{11} \mathrm{O}_{7}+5.5 \mathrm{O}_{2} \rightarrow 0.5 \mathrm{Na}_{2} \mathrm{CO}_{3}+5.5 \mathrm{CO}_{2}+5.5 \mathrm{H}_{2} \mathrm{O}
\end{gathered}
$$

Previous research on the specific healing agent has shown quite promising results with regard to sealing of micro-cracks after healing treatment (Jonkers et al., 2010; Wiktor and Jonkers, 2011; Jonkers and Mors, 2012; Sierra Beltran et al., 2015). In fact, it has been shown that the specific healing agent; i.e., bacteria spores, CaL and YE encapsulated in LWA, could promote and enhance the sealing capacity of mortar. Experimental results revealed that the maximum healable crack width was more than doubled (Wiktor and Jonkers, 2011) after the incorporation of the healing agent in the mortar.

The current paper focuses on the investigation of the most appropriate organic carbon source to be used as component of the healing agent. The methodology that was used for the selection process was based on: (a) continuous and non-continuous oxygen consumption measurements and (b) compressive strength tests. The selection was conducted among three different organic compounds, namely $\mathrm{CaL}, \mathrm{CaA}$, and $\mathrm{NaG}$. The three compounds that were used for this research were chosen because they were all suitable nutrient sources for the applied bacterial strains, economical, and commercially available in bulk amounts.

\section{MATERIALS AND METHODS}

\section{Preparation of Bacterial Cultures}

Three alkali-resistant bacterial isolates related to the genus Bacillus were previously obtained from enrichment cultures inoculated with sediment derived from alkaline natural lakes Chiprana-Playa
(Spain), Kulunda (Siberia, Russia), and Wadi Natrun (Egypt) and tentatively named Iso-01, Iso-06, and Iso-10, respectively. Phylogenetic analysis based on partial 16S rRNA gene sequence analysis revealed that isolate Iso-01 was most closely related to the scientifically described alkaliphilic species Bacillus cohnii (>99\% sequence homology), and isolates Iso-06 and Iso-10 to Bacillus alkalinitrilicus (both $>98 \%$ sequence homology).

Isolates are routinely cultured in alkaline medium with the following composition per liter of demineralized water: $0.375 \mathrm{~g}$ $\mathrm{KNO}_{3}, 0.2 \mathrm{~g} \mathrm{NH}_{4} \mathrm{CL}, 0.02 \mathrm{~g} \mathrm{KH}_{2} \mathrm{PO}_{4}, 0.225 \mathrm{~g} \mathrm{CaCl}_{2} .2 \mathrm{H}_{2} \mathrm{O}, 0.2 \mathrm{~g}$ $\mathrm{KCl}, 0.2 \mathrm{~g} \mathrm{MgCl}_{2} \cdot 6 \mathrm{H}_{2} \mathrm{O}$, sodium sesqui carbonate/bicarbonate buffer $\left(0.42 \mathrm{~g} \mathrm{NaHCO}_{3}\right.$ and $\left.0.53 \mathrm{~g} \mathrm{Na}_{2} \mathrm{CO}_{3}\right), 1 \mathrm{~g} \mathrm{YE}, 1 \mathrm{ml}$ trace element solution SL-12B, and an additional organic carbon source (either lactate $1 \mathrm{~g} / \mathrm{l}$, acetate $0.8 \mathrm{~g} / \mathrm{l}$, or gluconate $2 \mathrm{~g} / \mathrm{l}$ ). The $\mathrm{pH}$ of the medium was 9.8 . The cultivation was done aerobically by incubation of cultures in cotton wool stoppered Erlenmeyer tubes on a shaking table at $150 \mathrm{rpm}$.

For experimental assays (oxygen consumption measurements), cultures were pre-grown as described above followed by centrifugation and resuspension of the cell pellet in $0.1 \mathrm{M}$ sesqui buffer amended with one of the specific substrates under investigation $(\mathrm{CaL}, \mathrm{CaA}$, and $\mathrm{NaG})$ at a final concentration of $0.1 \mathrm{M}$.

\section{Continuous Oxygen Consumption Measurements}

Almost an hour after the preparation of the washed bacterial suspensions, oxygen consumption measurements took place in order to evaluate the preference of each isolate to a certain organic compound. The measurements were conducted in transparent glass flasks, which contained a sensor spot (SP-PSt3, PreSensPrecision Sensing $\mathrm{GmbH}$ ) glued on the inner part of their wall, as it is depicted in Figure 1.

The volume capacity of the flasks was $15 \mathrm{ml}$. The flasks were either filled only with the cell suspension (Iso-01, Iso-06, or Iso-10) or with $13.5 \mathrm{ml}$ cell suspension and $1.5 \mathrm{ml}$ compound solution ( $\mathrm{CaL}, \mathrm{CaA}$, or $\mathrm{NaG}$ ) of $0.1 \mathrm{M}$. The oxygen concentration (in micromoles) inside the sealed flask was measured with a battery powered Fibox 4 oxygen meter (PreSens-Precision Sensing $\mathrm{GmbH}$ ). A polymer optical fiber (POF) connected to the oxygen meter was used to transfer excitation light to the sensor and the sensor response back to the meter. The POF enabled non-invasive and non-destructive measurements to be made in the sealed flask from outside through its transparent wall. Frequent measurements were taken every $5 \mathrm{~min}$. Each experiment lasted approximately from 30 until $120 \mathrm{~min}$, depending on the oxygen consumption rate of each isolate. A typical graph obtained after the completion of the test is presented in Figure 2. From the graph, it was possible to calculate the slope of each curve in micromoles per minute as it shown in Figure 2. The slope of each curve (consumption rate, $\kappa$ ) was the base of comparison for this set of experiments.

\section{Biolog Test (Non-Continuous Oxygen Consumption Measurement)}

Isolates Iso-01, Iso-06, and Iso-10 were prior to further experimental testing characterized with respect to aerobically metabolizable substrates. Therefore, commercial 96-well Biolog plates were used, which feature a specific organic compound in 


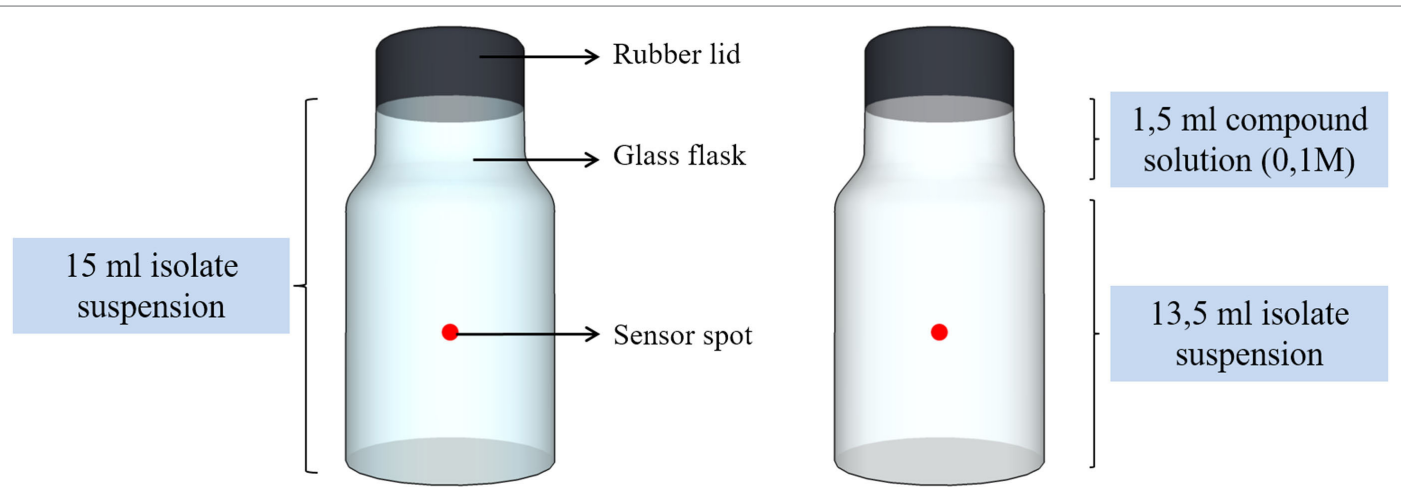

FIGURE 1 | Glass flasks with oxygen sensor spots attached in the inner wall of the flasks.

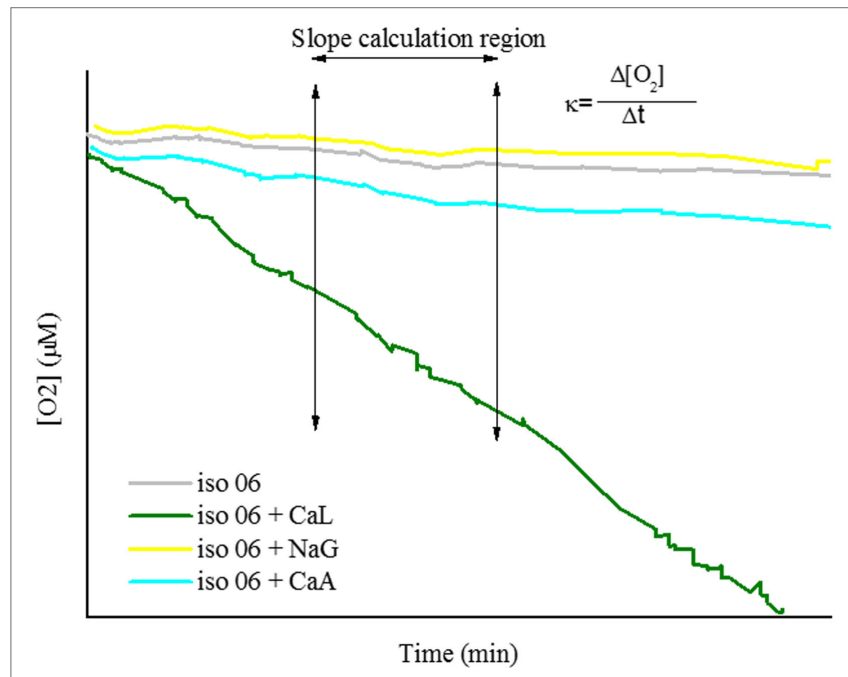

FIGURE 2 | Typical graph obtained by oxygen consumption test. Four different curves are presented; the curve of autogenous respiration of vegetative cells (iso-06), the curve of vegetative cells respiring in calcium lactate (CaL) (iso-06 + CaL), the curve of vegetative cells respiring in calcium acetate $(\mathrm{CaA})$ (iso-06 + $\mathrm{CaA})$, and the curve of vegetative cells respiring in sodium gluconate $(\mathrm{NaG})$ (iso-06 + $\mathrm{NaG}$ ).

each of 95 wells leaving the last well as blank. Each of the $0.2 \mathrm{ml}$ volume wells were filled with $0.18 \mathrm{ml}$ washed cell suspension and incubated aseptically at room temperature $\left(20 \pm 2^{\circ} \mathrm{C}\right)$. After $48 \mathrm{~h}$ of incubation, the oxygen concentration in each of the wells was measured by inserting an oxygen micro-sensor (Fiber optic oxygen sensor, PreSens-Precision Sensing $\mathrm{GmbH}$ ) halfway into the liquid. Decrease of oxygen concentration relative to the control well (not containing any organic substrate) was indicative for the metabolizability of the specific organic substrate by the specific isolate.

\section{Mechanical Testing}

The healing agent (bacteria spores, organic compound, and YE) under investigation is loaded into lightweight expanded clay particles (Liapor 0/4 mm, Liapor $\mathrm{GmbH}$, Germany) followed by mixing with the fresh mortar paste. For the loading procedure of the LWA, the healing agent compounds were dissolved in water and then via impregnation under vacuum, the healing agent was incorporated into the LWA. Following the impregnation, the LWA were dried for approximately for 5-6 days at standard at temperature $\left(20 \pm 2^{\circ} \mathrm{C}\right)$ with $(60 \pm 10) \% \mathrm{RH}$, until a constant weight was achieved. After drying, it was found that the initial dry weight of the LWA increased by approximately $10 \%$. It was, therefore, needed to examine how the compressive strength would be affected by a possible leakage of the healing agent (from the LWA into the matrix) during mixing and setting of the mortar. As a result, compressive tests on mortar cubes $(40 \mathrm{~mm} \times 40 \mathrm{~mm} \times 40 \mathrm{~mm})$ were conducted according to EN 1015-11 at the age of 28 days. Five different amounts of compounds ( $\mathrm{CaL}$ and $\mathrm{CaA}$ ) were tested; $0,0.56,1.12,1.68$, and $2.24 \%$ per cement weight. The examined percentages were representing the amount of healing agent that could possibly leak in the mortar matrix; $0,10,20,30$, and $40 \%$, respectively. An example of the calculation of those percentages is presented below.

- The amount of the (unloaded) LWA added in the mortar mixture is $257 \mathrm{~g}$.

- The amount of cement added in the mortar mixture is $463 \mathrm{~g}$.

- The LWA increase their dry weight by $10 \%$ after the impregnation. Therefore, the healing agent embedded is $25.7 \mathrm{~g}$ (total weight of loaded LWA is $257 \mathrm{~g}+25.7 \mathrm{~g} \approx 283 \mathrm{~g}$ ).

- The $10 \%$ of the incorporated healing agent that might leak in the mortar matrix will be then $2.57 \mathrm{~g}$ and, consequently, $2.57 \mathrm{~g} / 463 \mathrm{~g}=0.56 \%$ per cement weight.

The mix design of the examined mixtures is presented in Table 1. The organic compound was dissolved in the mixing water. The mixing and casting of the mortars, which contained $\mathrm{CaL}$ took place on a different period from the mortars with $\mathrm{CaA}$. Therefore, the environmental conditions differed, as well as, the materials that were used for the casting (cement and aggregates) originated from different batches. Consequently, it was decided that the reference mixture (with $0 \%$ organic compound) was needed to be cast twice in order to have an objective comparison. Five cubic specimens per mixture were tested. 


\section{RESULTS}

\section{Continuous Oxygen Consumption Measurements}

The results from the continuous oxygen consumption measurements from the respiration of vegetative cells pre-grown in the three media are presented in Figure 3. The graphs show the relative (normalized) respiration rate $(r)$ for each bacterial isolate respiring in the three different organic compounds after pregrowing in one of them. The normalization of the respiration rate is made by dividing the slope of a respiration curve (in a certain compound) by the slope of the autogenous respiration curve of the same isolate. The calculation formula of $r$ is shown in Eq. 4. Where $\kappa_{\mathrm{a}}$ is the slope of the autogenous respiration curve (no

TABLE 1 | Mix design of the mortars.

\begin{tabular}{lc}
\hline Compound & Amount $\mathbf{( k g / \mathbf { m } ^ { 3 } )}$ \\
\hline CEM I & 463 \\
Water (with or without dissolved organic compound) & 231.5 \\
Sand 0.125/1 mm & 855 \\
Non-loaded Liapor $1 / 4 \mathrm{~mm}$ & 257
\end{tabular}

organic compound in the flask) and $\kappa_{c}$ is the slope of the curve from the cell respiration in a certain compound.

$$
\mathbf{r}=\frac{\kappa_{\mathrm{c}}-\kappa_{\mathrm{a}}}{\kappa_{\mathrm{a}}} \times 100 \%
$$

\section{Isolates Pre-Grown on Lactate}

The isolates pre-grown in lactate showed a definite preference in respiring on the same compound. Iso-06 exhibits a remarkable preference for $\mathrm{CaL}$, almost eight times more than the autogenous respiration. Iso-01 and Iso-10 also increased their autogenous respiration rate, however, considerably less than Iso-06. When $\mathrm{CaA}$ was used as nutrient for the vegetative cells, the respiration rates showed a rather limited increase. Iso-06 showed a bias for respiring in $\mathrm{CaA}$, but the other two isolates did not. Respiration rates on $\mathrm{NaG}$ were noticeably lower for all three isolates. Slightly low negative relative respiration rates were observed for Iso-01 and Iso-06 respiring in $\mathrm{CaA}$ and $\mathrm{NaG}$, respectively. This phenomenon can be attributed to the "dilution" of the cell suspension. In fact, the density of the cell suspensions decreased when the solution with the organic compound was added, since the flasks contained of $13.5 \mathrm{ml}$ instead $15 \mathrm{ml}$ of cell suspension. This means that the oxygen consumption did not actually slow down, but it

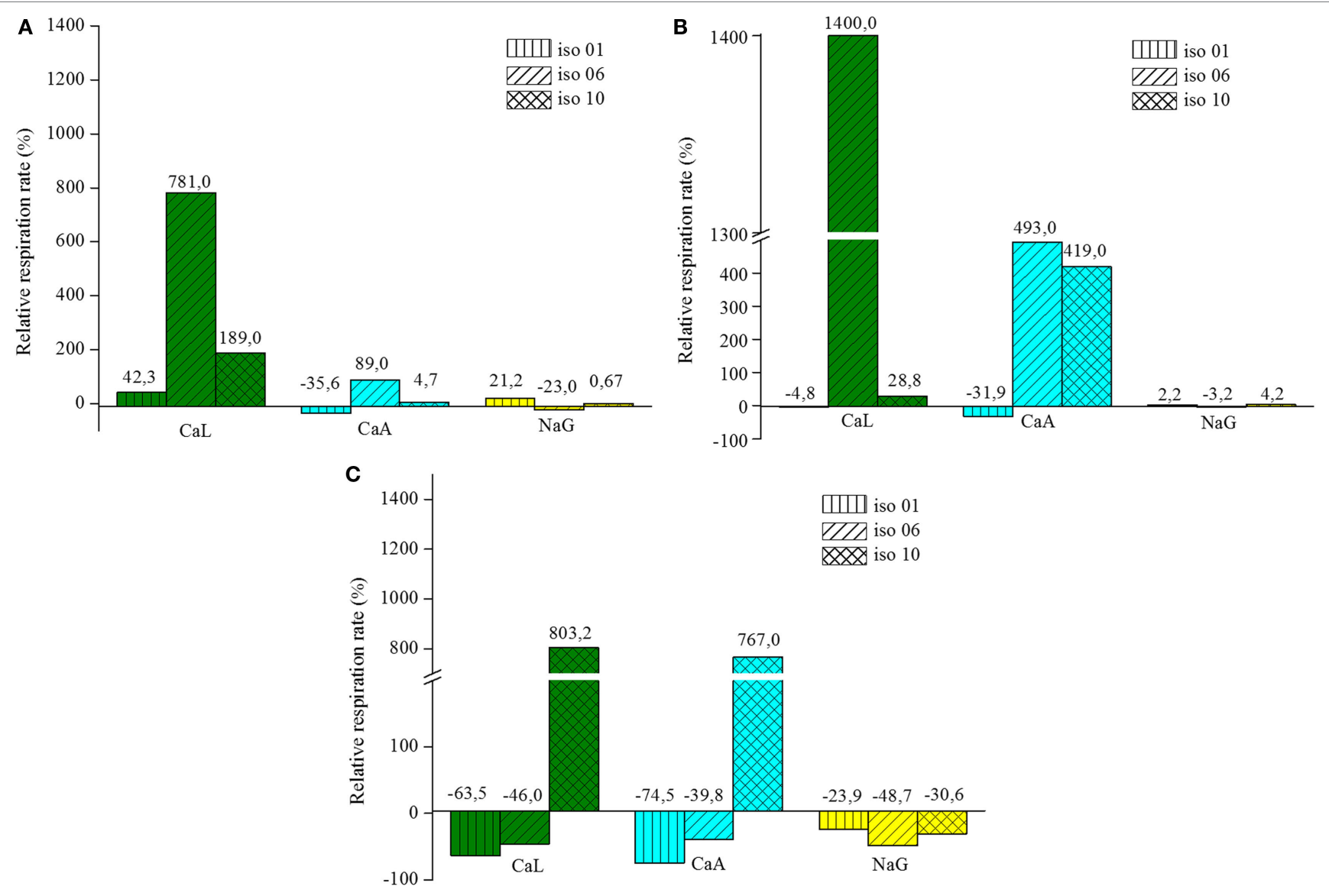

FIGURE 3 | Relative respiration rate of vegetative cells pre-grown in: (A) lactate, (B) acetate, and (C) gluconate. 
was the decreased amount of cells in the flask that caused this effect.

\section{Isolates Pre-Grown on Acetate}

Iso-06 pre-grown in acetate exhibited also a very significant increase in oxygen consumption rate for respiring on CaL. In addition, Iso-06 and Iso-10 pre-grown in acetate, increased their consumption rate (almost 4-5 times), when respiring in CaA. On the other hand, the respiration of Iso-01 pre-grown in acetate seemed unaffected regardless of the organic compound that was added. Furthermore, the presence of $\mathrm{NaG}$ in the flask did not influence the autogenous respiration of any of the isolates.

\section{Isolates Pre-Grown on Gluconate}

Iso-10 pre-grown in gluconate, was the only cell suspension that exhibited positive relative respiration values for respiring on $\mathrm{CaL}$ or on $\mathrm{CaA}$. The other combinations of isolates and organic media showed negative relative respiration rate values. In some cases,

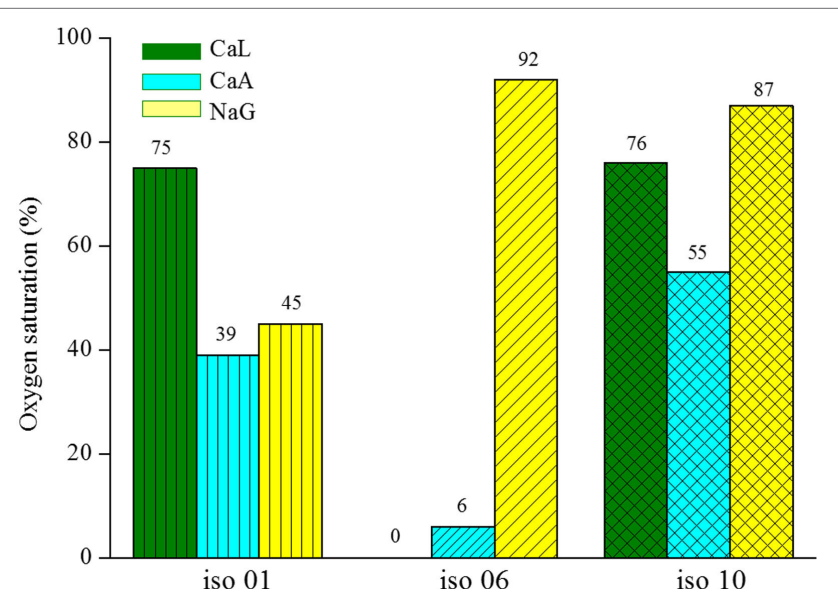

FIGURE 4 | Oxygen saturation level of the three different bacteria isolates respiring on calcium lactate $(\mathrm{CaL})$, calcium acetate $(\mathrm{CaA})$, or sodium gluconate (NaG). for example Iso-01 respiring on $\mathrm{CaL}$ or on $\mathrm{CaA}$, the negative values exceeded the limit (approximately 20-30\% lower than autogenous respiration) where it can be attributed to the dilution of the cell suspension.

\section{Biolog Test}

The Biolog test follows essentially the same principle as the continuous oxygen consumption test, since they both rely on oxygen reduction, due to respiration of vegetative cells. However, the duration of the tests and the way of monitoring the oxygen reduction are different. The results obtained by the Biolog test are shown in Figure 4. The $y$-axis of the graph indicates the air saturation in the control well at $48 \mathrm{~h}$. The results show that all three isolates show a preference for $\mathrm{CaA}$, while they appear to be able to degrade $\mathrm{CaL}$ and $\mathrm{NaG}$, but in a less efficient way. Iso-06 was the only isolate, which was able to consume almost all oxygen when exposed to CaL and CaA.

\section{Compressive Strength of Mortar Cubes}

After considering the response of the three isolates in the three different organic compounds from both continuous oxygen consumption measurements and the Biolog test, it was decided that only two of them, namely $\mathrm{CaL}$ and $\mathrm{CaA}$, will be tested for their effect on compressive strength development of mortar. Figure 5 shows the average (out of five cubic specimens) compressive strength of each mixture, as well as, the deviation from the reference mixture. The results revealed that, in general, the addition of the two organic compounds in the mixing water of mortar either increased or not affected the compressive strength at the amounts that were tested. Mixtures with dissolved $\mathrm{CaL}$ and $\mathrm{CaA}$ in the mixing water showed the same trend in the development of strength according to the varying amounts of the organics. Specifically, for mixtures with dissolved $\mathrm{CaL}$, the compressive strength ranged from -1.46 to $7.98 \%$ compared to the reference mixture, while for $\mathrm{CaA}$, the increase varied from 0.12 to $13.43 \%$. Although both organic compounds showed a relatively similar response when added in the mixing water of the mortar, it was decided that the research will be continued with $\mathrm{CaL}$, as bacterial nutrient.

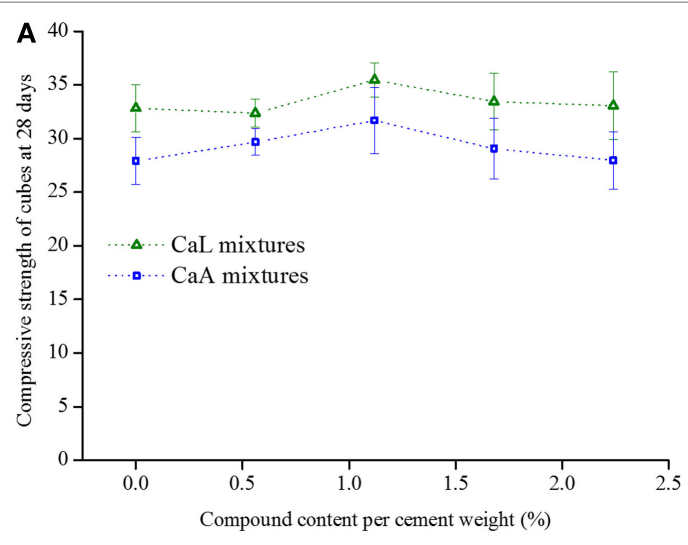

B

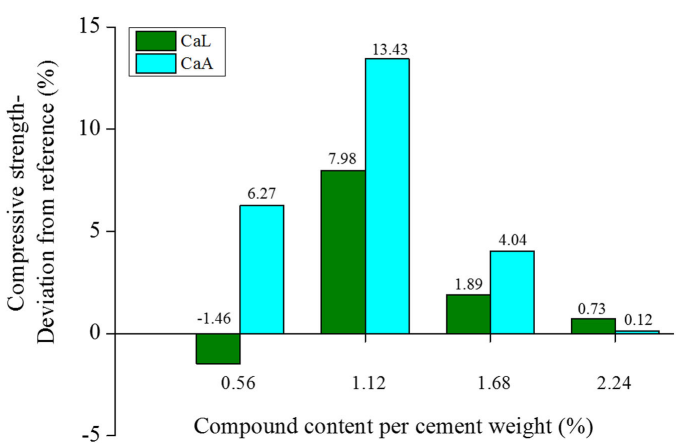

FIGURE 5 | (A) Compressive strength and (B) deviation of the compressive strength from the reference of mixtures containing different amounts of calcium lactate (CaL) and calcium acetate $(\mathrm{CaA})$. 
Two studies (Tziviloglou et al., 2016; Megalla, 2017), which preceded the current one showed that the specific healing agent either embedded in LWA or in polylactic acid particles showed enhanced crack sealing performance after the healing treatment in comparison to mortar samples without the healing agent. Tziviloglou et al. proved that the lightweight mortar with incorporated biogenic healing agent revealed improved crack sealing, particularly when subjected to wet-dry cycles. In fact, the biogenic specimens showed decreased crack permeability after the healing treatment of 28 and 56 days that reached 76 and $100 \%$, while the reference specimens exhibited a sealing recovery of 25 and $10 \%$, when subjected to the same treatment and for the same duration. The proof that the enhanced sealing behavior of the biogenic specimens is coming from the bacterial activity was supported by oxygen consumption measurements and bacterial imprints on crystal formations found in the microscopic observations. In addition, Megalla proved through crack permeability tests that full crack sealing occurred in the biogenic specimens, while only partial sealing occurred in the reference specimens. The bacterial-mediated process resulted in efficient sealing of cracks up to $0.47 \mathrm{~mm}$, after 56 days of water submersion. Optimal performance was observed for the specimens containing the loose components in a dose of $10 \mathrm{~kg} / \mathrm{m}^{3}$. In this study, the presence of bacterial activity was indicated by oxygen profile measurements. Finally, the study revealed that a damp environment was the most stimulating regime for the self-healing mechanism.

\section{DISCUSSION}

The results of the continuous oxygen measurements on washed bacterial cultures showed that the vegetative cells have a preference to respire on lactate when pre-grown in it. The same holds for acetate, but only for two out of the three studied isolates (Iso-06 and Iso-10). Due to this fact, it can be assumed that the cells develop a sort of memory, probably by induction of specific metabolic enzymes, when pre-grown on a certain substrate, which allows them to degrade it rather fast when they encounter it in their environment. However, this was not the case for gluconate. The cells that were initially grown on gluconate did not "recognize" it afterward in the flasks. This behavior can possibly be explained by the fact that the cells were not pre-grown exclusively on the specific organic compound (lactate, acetate, or gluconate), but also on a small amount of YE ( $1 \mathrm{~g} / \mathrm{l})$. Thus, it seemed that the culture could initially grow only on YE and not in gluconate. It was, therefore, expected to exhibit slight negative relative consumption rates when exposed to gluconate.

The Biolog test did not fully confirm the results that were obtained by the oxygen test. For example, it was derived (by the Biolog test) that $\mathrm{NaG}$ could be degraded by Iso- 01 , while the other two isolates exhibited much weaker response when exposed to it. On the other hand, the continuous oxygen consumption test revealed that none of the isolates could degrade $\mathrm{NaG}$, irrespectively of the pre-growth medium. In addition, the Biolog test revealed, in general, a higher preference for acetate than for lactate, which does not completely agree with the continuous oxygen measurements. Although both tests work by measuring the oxygen reduction, the results were slightly different. The variances in the results obtained by the two tests could be attributed to the two following facts:

- The duration of the tests. The continuous oxygen consumption measurements lasted between 30 and $120 \mathrm{~min}$, while the Biolog test lasted $48 \mathrm{~h}$.

- The basis of comparison of each test. The continuous oxygen consumption test was based on comparison between consumption rates, while the biolog test results were based only on a single value obtained $48 \mathrm{~h}$ after the initiation of the test.

In this study, the compressive strength was determined only at the age of 28 days and not earlier. It should be noted that in case the bacteria activity starts at an earlier age, the water produced during metabolic conversion of the organic compounds is insignificant and can not alter the water-to-cement ratio. Consequently, the compressive strength cannot be affected by the metabolic reaction.

The compressive tests revealed a rather positive influence of the two organic components, when dissolved in the mixing water. In general, the compressive strength at 28 days was either slightly increased or remained unaffected compared to the reference mixture. Thus, both organic compounds ( $\mathrm{CaL}$ and $\mathrm{CaA}$ ) could be used as parts of the biogenic healing agent without expecting negative effects on the strength of the cementitious material.

\section{CONCLUSION}

The current paper studied the nutrient preference of three different bacteria isolates that are used as part of biogenic healing agent for cementitious materials. Two methods, based on oxygen consumption, but with different duration and way of measuring were adapted. The continuous oxygen measurements showed a higher preference for $\mathrm{CaL}$, while the non-continuous oxygen measurements for $\mathrm{CaA}$. Both testing methods agreed that $\mathrm{NaG}$ is not appropriate source of nutrient for the specific isolates. Additionally, the continuous oxygen measurements revealed that the bacterial cells that can pre-grow in a certain organic compound can degrade it easily when they find it afterward in their environment. Therefore, a sort of memory can be developed. Finally, compressive strength tests on 28-day-old mortar cubes indicated that the two organic components; namely $\mathrm{CaL}$ and $\mathrm{CaA}$, either not affect or affect positively when dissolved in mixing water in amounts between 0.56 and $2.24 \%$ per cement weight.

\section{AUTHOR CONTRIBUTIONS}

ET was involved in experimental design, experimental work, data analysis, and manuscript writing. VW was involved in work conception, experimental work, and data analysis. HJ provided guidance on microbiology, he was involved in work conception and manuscript writing. ES coordinated the collaborative effort.

\section{FUNDING}

The authors acknowledge the financial support of European Union Seventh Framework Programme (FP7/2007-2013) under grant agreement no 309451 (HEALCON). 


\section{REFERENCES}

Anbu, P., Kang, C.-H., Shin, Y.-J., and So, J.-S. (2016). Formations of calcium carbonate minerals by bacteria and its multiple applications. Springerplus 5, 250. doi:10.1186/s40064-016-1869-2

De Muynck, W., Debrouwer, D., De Belie, N., and Verstraete, W. (2008). Bacterial carbonate precipitation improves the durability of cementitious materials. Cem. Concr. Res. 38, 1005-1014. doi:10.1016/j.cemconres.2008.03.005

de Rooij, M., Van Tittelboom, K., De Belie, N., and Schlangen, E. (2013). SelfHealing Phenomena in Cement-Based Materials: State-of-the-Art-Report of RILEM Technical Committee 221-SHC, RILEM State of the Art Reports; v. 11. Dordrecht, The Netherlands: Springer.

Ersan, Y. C. (2016). Microbial Nitrate Reduction Induced Autonomous Self-Healing in Concrete. Ph.D. thesis, Ghent University, Ghent.

Jonkers, H. M., and Mors, R. (2012). "Full scale application of bacteria-based self-healing concrete for repair purposes," in Concrete Repair, Rehabilitation and Retrofitting III - Proceedings of the 3rd International Conference on Concrete Repair, Rehabilitation and Retrofitting, ICCRRR 2012, Cape Town.

Jonkers, H. M., Thijssen, A., Copuroglu, O., Schlangen, E., and Muyzer, G. (2010). Application of bacteria as self-healing agent for the development of sustainable concrete. Ecol. Eng. 36, 230-235. doi:10.1016/j.ecoleng.2008.12.036

Jonkers, H. M., Wiktor, V., Sierra Beltran, M. G., Mors, R. M., Tziviloglou, E., and Palin, D. (2015). "Limestone-producing bacteria make concrete self healing," in Self-Healing Materials, eds S. Van der Zwaag and E. Brinkman (Amsterdam: IOS Press BV), 137-148.

Megalla, M. (2017). Bacteria Based Self-Healing Concrete. Master thesis, Delft University of Technology, Delft, The Netherlands.

Paine, K., Alazhari, M., Sharma, T., Cooper, R., and Health, A. (2016). "Design and performance of bacteria-based self-healing concrete," in 9th International Concrete Conference 2016, eds M. R. Jones, M. D. Newlands, J. E. Halliday, L. J. Csetenyi, L. Zheng, M. J. McCarthy, et al. (Dundee).

Ramachandran, S. K., Ramakrishnan, V., and Bang, S. S. (2001). Remediation of concrete using micro-organisms. ACI Mater. J. 98, 3-9. doi:10.14359/10154

Schlangen, E., and Joseph, C. (2009). "Self-healing processes in concrete," in SelfHealing Materials, ed. S. K. Gosh (Weinheim, Germany: Wiley-VCH Verlag GmbH \& Co. KGaA), 141-182.
Sierra Beltran, M. G., Jonkers, H. M., Mors, R. M., and Mera-Ortiz, W. (2015) "Field application of self-healing concrete with natural fibres as linings for irrigation canals in Ecuador," in 5th International Conference on Self-Healing Materials, Durham, NC, USA.

Stuckrath, C., Serpell, R., Valenzuela, L. M., and Lopez, M. (2014). Quantification of chemical and biological calcium carbonate precipitation: performance of self-healing in reinforced mortar containing chemical admixtures. Cem. Concr. Compos. 50, 10-15. doi:10.1016/j. cemconcomp.2014.02.005

Tziviloglou, E., Wiktor, V., Jonkers, H. M., and Schlangen, E. (2016). Bacteria-based self-healing concrete to increase liquid tightness of cracks. Constr. Build. Mater. 122, 118-125. doi:10.1016/j.conbuildmat.2016.06.080

Wang, J., Dewanckele, J., Cnudde, V., van Vlierberghe, S., Verstraete, W., and de Belie, N. (2014). X-ray computed tomography proof of bacterial based self-healing in concrete. Cem. Concr. Compos. 53, 289-304. doi:10.1016/j. cemconcomp.2014.07.014

Weiss, W. J. (1999). Prediction of Early Age Shrinkage Cracking in Concrete Elements. Ph.D. thesis, North-Eastern University, Evanston, IL.

Wiktor, V., and Jonkers, H. M. (2011). Quantification of crack-healing in novel bacteria-based self-healing concrete. Cem. Concr. Compos. 33, 763-770. doi:10.1016/j.cemconcomp.2011.03.012

$\mathrm{Xu}$, J., and Yao, W. (2014). Multiscale mechanical quantification of self-healing concrete incorporating non-ureolytic bacteria-based healing agent. Cem. Concr. Res. 64, 1-10. doi:10.1016/j.cemconres.2014.06.003

Conflict of Interest Statement: The authors declare that the research was conducted in the absence of any commercial or financial relationships that could be construed as a potential conflict of interest.

Copyright (c) 2017 Tziviloglou, Wiktor, Jonkers and Schlangen. This is an openaccess article distributed under the terms of the Creative Commons Attribution License (CC BY). The use, distribution or reproduction in other forums is permitted, provided the original author(s) or licensor are credited and that the original publication in this journal is cited, in accordance with accepted academic practice. No use, distribution or reproduction is permitted which does not comply with these terms. 